\title{
Correction to: Comparison of outcome after right colectomy with an enhanced recovery programme in patients with inflammatory bowel disease and patients operated on for other conditions: a monocentric retrospective study
}

\author{
Anne Meunier $^{1} \cdot$ Giuseppe Sorce $^{2} \cdot$ Pierre-Yves Hardy $^{1} \cdot$ Carla Coimbra $^{2} \cdot$ Emmanuel Decker $^{2} \cdot$ Jean $^{\text {Joris }}{ }^{1,3}$ iD \\ Published online: 28 January 2021 \\ (C) Springer-Verlag GmbH Germany, part of Springer Nature 2021
}

Correction to: International Journal of Colorectal Disease https://doi.org/10.1007/s00384-020-03830-5

The original published version of this article contained errors. The URL in the affiliation was presented incorrectly as "www.grace-asso.fr instead of www.grace-aaso.fr." This should have been "www.grace-asso.fr".

In the third paragraph under the "Discussion" section, the text IBM in the sentence "Tolerance of early feeding on the day of surgery was, however, lower than in IBD patients as also reported by others [18]." should read as "non-IBM". [Bold text used to highlight problem area]

The original article has been corrected.

Publisher's note Springer Nature remains neutral with regard to jurisdictional claims in published maps and institutional affiliations.

The online version of the original article can be found at https://doi.org/ 10.1007/s00384-020-03830-5

\footnotetext{
Jean Joris

jean.joris@chuliege.be

1 Department of Anaesthesiology and Reanimation, CHU Liège, University of Liège, Domaine universitaire du Sart Tilman, avenue de l'hôpital Bat B35, B-4000 Liège, Belgium

2 Service of Abdominal Surgery, CHU Liège, University of Liège, Domaine universitaire du Sart Tilman, Liège, Belgium

3 Groupe francophone de réhabilitation améliorée après chirurgie (GRACE; Francophone group for enhanced recovery after surgery, www.grace-asso.fr), Beaumont, France
} 